\title{
Estudos culturais, educação e pedagogia
}

\author{
Marisa Vorraber Costa \\ Universidade Federal do Rio Grande do Sul, Programa de Pós-Graduação em Educação \\ Universidade Luterana do Brasil, Programa de Pós-Graduação em Educação
}

\section{Rosa Hessel Silveira}

Universidade Federal do Rio Grande do Sul, Programa de Pós-Graduação em Educação

Universidade Luterana do Brasil, Programa de Pós-Graduação em Educação

\section{Luis Henrique Sommer}

Centro Universitário Feevale, RS

Universidade Luterana do Brasil, Faculdade de Educação

\section{Os estudos culturais: uma introdução}

O que é, afinal, Estudos Culturais? Esta frase e outras similares intitulam, no Brasil e em muitos países, alguns livros e artigos ${ }^{1}$ cujo objetivo tem sido definir os contornos da movimentação intelectual que surge no panorama político do pós-guerra, na Inglaterra, nos meados do século XX, provocando uma grande reviravolta na teoria cultural. Se continuarmos a percorrer as publicações, perceberemos, entre os textos mais disseminados, que as preocupações se concentram em problematizações da cultura, agora entendida em um espectro mais amplo de possibilidades no qual despontam os domínios do popular. Aliás, a revolução copernicana operada pelos Estudos Culturais na teoria cultural concentrou-se neste terreno escorregadio e eivado de preconceitos em que se cruzam duas noções ou concepções ex-

${ }^{1}$ Citamos como exemplos: John Storey (1997); Cary Nelson; Paula Treichler, Lawrence Grossberg (1992); Richard Johnson (1986/1987); Tomaz Tadeu Silva (1999b). tremamente complexas e matizadas como cultura e popular. $^{2}$

Cultura transmuta-se de um conceito impregnado de distinção, hierarquia e elitismos segregacionistas para um outro eixo de significados em que se abre um amplo leque de sentidos cambiantes e versáteis. Cultura deixa, gradativamente, de ser domínio exclusivo da erudição, da tradição literária e artística, de padrões estéticos elitizados e passa a contemplar, também, o gosto das multidões. Em sua flexão plural - culturas - e adjetivado, o conceito incorpora novas e diferentes possibilidades de sentido. É assim que podemos nos referir, por exemplo, à cultura de massa, típico produto da indústria cultural ou da sociedade techno contemporânea, bem como às culturas juvenis, à cultura surda, à cultura empresarial, ou às culturas indígenas, expressando

${ }^{2}$ Ver, a este respeito, o capítulo 1 do livro Estudos culturais em educação, organizado por Marisa Vorraber Costa (2000), e também o artigo Cultura, culturas e educação, de Alfredo VeigaNeto, neste número da Revista Brasileira de Educação. 
a diversificação e a singularização que o conceito comporta.

Ao par disso, o termo popular também é objeto de uma vicejante polissemia. Do popular ao pop, ${ }^{3}$ nomeiam-se movimentações das mais variadas gamas. Popular tanto pode indicar breguice, gostos e condutas comuns do povo, entendido como a numerosa parcela mais simples e menos aquinhoada da população, quanto, na nomenclatura política das esquerdas, expressar o fetiche do mundo intelectual politicamente engajado ou mesmo as cruzadas contemporâneas em torno do politicamente correto. Nesta oscilação cambiante do significado, popular e pop comportam gradações que, com freqüência, apontam para distinções entre o que é popularesco, rebuscado, kitsch e o que é sofisticado, despojado, minimalista. Como se percebe, as palavras têm história, vibram, vivem, produzem sentidos, ao mesmo tempo em que vão incorporando nuanças, flexionadas nas arenas políticas em que o significado é negociado e renegociado, permanentemente, em lutas que se travam no campo do simbólico e do discursivo.

Os Estudos Culturais (EC) vão surgir em meio às movimentações de certos grupos sociais que buscam se apropriar de instrumentais, de ferramentas conceituais, de saberes que emergem de suas leituras do mundo, repudiando aqueles que se interpõem, ao longo dos séculos, aos anseios por uma cultura pautada por oportunidades democráticas, assentada na educação de livre acesso. Uma educação em que as pessoas comuns, o povo, pudessem ter seus saberes valorizados e seus interesses contemplados. O projeto inicial dos Estudos Culturais britânicos ${ }^{4}$ era "um projeto de pensar as implicações da extensão do termo 'cultura' para que inclua atividades e significados das pessoas comuns, esses coletivos excluídos da partici-

${ }^{3}$ Há breve crônica de Juremir Machado da Silva sobre esse tópico (2003).

${ }^{4}$ Essa movimentação no campo da teoria cultural é fartamente documentada no que se refere às suas manifestações na Inglaterra, sendo amplamente difundido e reconhecido que este pação na cultura quando é a definição elitista que a governa" (Barker \& Beezer, 1994, p. 12). ${ }^{5}$

Desde seu surgimento, os EC configuram espaços alternativos de atuação para fazer frente às tradições elitistas que persistem exaltando uma distinção hierárquica entre alta cultura e cultura de massa, entre cultura burguesa e cultura operária, entre cultura erudita e cultura popular. Nessa disposiçao hierárquica, ao primeiro termo corresponderia sempre $a$ cultura, entendida como a máxima expressão do espírito humano; segundo a tradição arnoldiana, ${ }^{6}$ "o melhor que se pensou e disse no mundo". Ao segundo termo corresponderiam as [outras] culturas, adjetivadas e singulares, expressão de manifestações supostamente menores e sem relevância no cenário elitista dos séculos XVIII, XIX e XX. Harmonia e beleza eram prerrogativas da cultura, que deveria ser cultivada para fazer frente à barbárie dos grupos populares, cuja vida se caracterizaria pela indigência estética e pela desordem social e política. Só a harmonia suscitada pela "verdadeira cultura" poderia

país teria sido o berço dos EC. Contudo, o acesso à literatura mais recente, em línguas que não a inglesa (por exemplo Mato, 2001; Martín-Barbero, 1997a), parece sugerir que tal reviravolta nos estudos da cultura teria ocorrido, quase simultaneamente, também em outros países europeus, asiáticos e latino-americanos, expressando um certo "estado das discussões sobre cultura" que vai se instaurar em vários locais do mundo, num tempo de grandes reviravoltas na organização do capitalismo, produzidas, em grande parte, pelos avanços nas tecnologias da informação e da comunicação, as quais, usando a expressão do filósofo italiano Gianni Vattimo (1991), estariam deixando as sociedades "trasparentes" e favorecendo a inscrição de outros grupos e sujeitos coletivos no mapa cultural e político do século XX. Ver a esse respeito a seção do presente texto que aborda os EC na América Latina

${ }^{5}$ Todas as traduções de originais em espanhol e em inglês são dos autores deste artigo.

${ }^{6}$ Expressão que faz referência a Mathew Arnold, autor de Culture and anarchy e teórico principal de uma tradição de análise da cultura fortemente marcada por posições elitistas e hierárquicas. 
apaziguar os ânimos, aplacar a ignorância e suprimir a anarquia da classe trabalhadora parcamente instruída.

A tradição arnoldiana teve defensores arraigados no século XX, que pretenderam fazer frente ao suposto declínio cultural, à padronização da cultura e ao nivelamento por baixo prognosticado por Arnold muitas décadas antes. Diante do risco do "irremediável caos" que representariam os "temíveis avanços da cultura de massa", chegou a ser publicado um manifesto propondo introduzir nos currículos escolares um treinamento de resistência à cultura de massa, qualificada como uma cultura comercial consumida por uma maioria ignorante e inculta. Contra isso, pretendiam criar postos avançados em escolas e universidades, nas quais grupos seletos de intelectuais atuariam como "missionários" em defesa da "verdadeira cultura!” É, então, a essa concepção elitista - em que cultura é um certo "estado cultivado do espírito", que estaria em oposição "à exterioridade da civilização" que os EC vão se contrapor. ${ }^{7}$

Os trabalhos precursores dos EC, apesar de não serem unívocos em suas perspectivas de problematização, estão unidos por uma abordagem cuja ênfase recai sobre a importância de se analisar o conjunto da produção cultural de uma sociedade - seus diferentes textos $^{8}$ e suas práticas - para entender os padrões de comportamento e a constelação de idéias compartilhadas por homens e mulheres que nela vivem. Em seus desdobramentos, os EC investem intensamente nas discussões sobre a cultura, colocando a ênfase no seu significado político.

John Frow e Meaghan Morris (1997), autor e autora australianos, referem-se à cultura "não como uma

\footnotetext{
${ }^{7}$ Ver a esse respeito o capítulo 1 do livro Estudos culturais
} em educação: mídia, arquitetura, brinquedo, biologia, literatura, cinema..., organizado por Marisa Vorraber Costa (2000).

${ }^{8}$ Aqui a palavra textos não faz referência apenas às expressões da cultura letrada, mas a todas as produções culturais que carregam e produzem significados. Um filme, um quadro, uma foto, um mapa, um traje, uma peça publicitária ou de artesanato podem ser considerados textos culturais. expressão orgânica de uma comunidade, nem como uma esfera autônoma de formas estéticas, mas como um contestado e conflituoso conjunto de práticas de representação ligadas ao processo de composição e recomposição dos grupos sociais"(p. 345). Por sua vez, Stuart Hall (1997a e 1997c) diz que na ótica dos EC as sociedades capitalistas são lugares da desigualdade no que se refere a etnia, sexo, gerações e classes, sendo a cultura o locus central em que são estabelecidas e contestadas tais distinções. É na esfera cultural que se dá a luta pela significação, na qual os grupos subordinados procuram fazer frente à imposição de significados que sustentam os interesses dos grupos mais poderosos. Nesse sentido, os textos culturais são o próprio local onde o significado é negociado e fixado.

Analistas contemporâneos da cultura chamam a atenção para a ocorrência de uma "revolução cultural", ao longo do século XX, na qual os domínios do que costumamos designar como cultura se expandiram e diversificaram de uma forma jamais imaginada. A cultura não pode mais ser concebida como acumulação de saberes ou processo estético, intelectual ou espiritual. A cultura precisa ser estudada e compreendida tendo-se em conta a enorme expansão de tudo que está associado a ela, e o papel constitutivo que assumiu em todos os aspectos da vida social. Essa centralidade da cultura - ressaltada, entre tantos pensadores, por Stuart Hall, Fredric Jameson, Néstor Canclini, Beatriz Sarlo, David Harvey - tem uma dimensão epistemológica, que vem sendo denominada "virada cultural", referindo-se a esse poder instituidor de que são dotados os discursos circulantes no circuito da cultura. Um noticiário de televisão, as imagens, gráficos etc. de um livro didático ou as músicas de um grupo de rock, por exemplo, não são apenas manifestações culturais. Eles são artefatos produtivos, são práticas de representação, inventam sentidos que circulam e operam nas arenas culturais onde o significado é negociado e as hierarquias são estabelecidas. Para Hall (1997b),

\footnotetext{
[...] a cultura é agora um dos elementos mais dinâmicos -e mais imprevisíveis - da mudança histórica do novo milê-
} 
nio. Não devemos nos surpreender, então, que as lutas pelo poder deixem de ter uma forma simplesmente física e compulsiva para serem cada vez mais simbólicas e discursivas, e que o poder em si assuma, progressivamente, a forma de uma política cultural. (p. 20)

Haveria duas importantes determinantes históricas para a emergência e o desenvolvimento dos EC (Schwarz, 2000, p. 48-49). A primeira seria a reorganização de todo o campo das relações culturais em decorrência do impacto do capitalismo no surgimento de novas formas culturais - TV, publicidade, música rock, jornais e revistas de grande tiragem e circulação - que levam à dissolução o campo de forças do poder cultural das elites. A segunda teria sido o colapso do império britânico, cujo mapa territorial do poder diminui significativamente após a guerra contra o Egito em 1956, revirando o imaginário social da Inglaterra. Nessa experiência comum do fim do Império, a migração dos colonizados para sua "casa imaginada" - a Inglaterra - coloca em primeiro plano as preocupações políticas com as questões coloniais, sendo que alguns dos intelectuais que contribuíram para esse redirecionamento das discussões culturais foram formados na tradição britânica fora da própria Inglaterra. ${ }^{9}$ Surge uma nova geração intelectual com novos posicionamentos, idéias e críticas. Para Schwarz (2000), os Cultural Studies, na Inglaterra, foram uma "resposta directa à larga renarrativização da Inglaterra" (p. 49). Sua leitura vai mais adiante, contestando uma certa visão que coloca esses estudos como algo autóctone, que teria emergido de uma matriz centralizadora britânica. De fato, diz ele, muitos dos líderes intelectuais deste projeto eram periféricos a esta matriz.

${ }^{9}$ Este é o caso, por exemplo, de Stuart Hall (jamaicano), Gayatri Spivak (indiana), Edward Said (palestino nascido em Jerusalém que vive no eixo Inglaterra e Estados Unidos). Schwarz (2000, p. 57) menciona a afirmação de Hall de que no seu agrupamento de socialistas, em Oxford, de onde surgiu a Nova Esquerda e o grande impulso para os Cultural Studies, não havia um único inglês.
Assim, a queda dos impérios coloniais e os novos contornos da cultura no capitalismo teriam marcado acentuadamente o surgimento destas movimentações na teoria cultural. O mais antigo movimento dos estudos culturais teria surgido de uma variante paroquial e provinciana. As obras The uses of literacy (Richard Hoggart, 1957), Culture and Society (Raymond Williams, 1958), The long revolution (Williams, 1961) e The making of the english working class (E. P. Thompson, 1963) foram todas anteriores à disseminação da eletricidade como principal forma de energia e a conseqüente popularização de aparatos tecnológicos que iriam transformar radicalmente o acesso à informação e à comunicação. Hoggart só teria adquirido um aparelho de televisão após ter publicado The uses of literacy (Schwarz, 2000). Mesmo nesta fase, não se pode dizer que os EC estavam centrados em torno dos mesmos propósitos, projetos teóricos e políticos ou perspectivas analíticas. De fato, eles teriam sido uma tentativa de reordenar as concepções de classe e cultura, focalizando-as no simbólico e no vivido e tentando associar as culturas vivas ao poder. Muitas foram as incorporações em termos de formas de estudo e perspectivas teóricas, inclusive com repercussões no marxismo, passando as relações de classe a serem vistas como constituídas dentro e fora do local de trabalho, na cultura. A questão do poder foi remetida para o centro das discussões; se ele não estava nas estruturas do capital, precisava ser problematizado na linguagem, no simbólico, no inconsciente. Todo esse ecletismo resultou proveitoso, remexeu as tradições intelectuais e permitiu que novos desafios fossem formulados e enfrentados (Schwarz, 2000).

Os Estudos Culturais não constituem um conjunto articulado de idéias e pensamento. Como dizem seus cronistas mais contundentes, eles são e sempre foram um conjunto de formações instáveis e descentradas. Há tantos itinerários de pesquisa e tão diferentes posições teóricas que eles poderiam ser descritos como um tumulto teórico. Para Stuart Hall uma de suas figuras mais proeminentes e um dos mais conhecidos analistas contemporâneos da cul- 
tura - os Estudos Culturais se constituíram como um projeto político de oposição, e suas movimentações "sempre foram acompanhadas de transtorno, discussão, ansiedades instáveis e um silêncio inquietante" (Hall, 1996, p. 263).

\section{U ma teoria viajante - temas, tensões, problemas e aproximações}

Foi Heloisa Buarque de Holanda ${ }^{10}$ quem usou a expressão teoria viajante para referir-se aos Estudos Culturais, atribuindo-lhes um certo ethos, uma vocação para transitar por variados universos simbólicos e culturais, por vários campos temáticos e teorias, encontrando portos de ancoragem onde se deixam ficar e começam a produzir novas problematizações. Os Estudos Culturais não pretendem ser uma disciplina acadêmica no sentido tradicional, com contornos nitidamente delineados, um campo de produção de discursos com fronteiras balizadas. Ao contrário, o que os tem caracterizado é serem um conjunto de abordagens, problematizações e reflexões situadas na confluência de vários campos já estabelecidos, é buscarem inspiração em diferentes teorias, é romperem certas lógicas cristalizadas e hibridizarem concepções consagradas.

Os Estudos Culturais disseminaram-se nas artes, nas humanidades, nas ciências sociais e inclusive nas ciências naturais e na tecnologia. Eles prosseguem ancorando nos mais variados campos, e têm se apropriado de teorias e metodologias da antropologia, psicologia, lingüística, teoria da arte, crítica literária, filosofia, ciência política, musicologia... Suas pesquisas utilizam-se da etnografia, da análise textual e do discurso, da psicanálise e de tantos outros caminhos investigativos que são inventados para poder compor seus objetos de estudo e corresponder a seus propósitos. Eles percorrem disciplinas e metodologias para

${ }^{10} \mathrm{~A}$ expressão é usada no texto A academia entre o local e o global, publicado em $Z$ - Revista Eletrônica do PACC/UFRJ. Disponível em: <www.ufrj.br/pacc/z.html〉. dar conta de suas preocupações, motivações e interesses teóricos e políticos.

As contribuições de importantes pensadores sociais dos meados do século XX, como Louis Althusser e Antonio Gramsci, juntamente com as análises culturais de Raymond Williams, Richard Hoggart, Edward P. Thompson e Stuart Hall, ligados às movimentações iniciais da Nova Esquerda, ajudaram a forjar a primeira linhagem de análises culturais contemporâneas identificadas como Cultural Studies. Hall (1996) relata associações dos EC com o surgimento da primeira Nova Esquerda britânica, num momento de desintegração de um certo tipo de marxismo, aquele que se desmantelava diante da visão dos tanques soviéticos invadindo Budapest, em 1956, e transformando em cacos um projeto histórico-político. Boa parte daqueles que participaram do surgimento da Nova Esquerda pretendiam juntar estes fragmentos para recompor a agenda do marxismo como projeto político e trabalhar relativamente àquelas questões que ainda importavam e que poderiam significar contribuições importantes a um projeto como o dos EC. Assim, diz Hall (idem, p. 265), trabalhava-se o marxismo, trabalhando contra ele e com ele para tentar desenvolvê-lo.

Como concordam vários autores (Angela McRobbie, Cary Nelson, Lawrence Grossberg, Paula Treichler, Richard Johnson, Stuart Hall e outros/as), os Estudos Culturais de origem britânica têm sido um terreno conturbado de discussões e desencontros. Sardar e Van Loon (1998, p. 52) apresentam um apanhado das críticas, que contestam seu paroquialismo e anglocentrismo, sua ênfase nas questões de classe (em sua fase inicial), em detrimento de raça e gênero, e sua abordagem preferencial das expressões urbanas metropolitanas e dos rituais das assim chamadas subculturas. Os EC teriam erigido a cultura popular britânica como modelar, compartilhando, mais uma vez, uma noção de arte particularmente eurocêntrica em que são celebradas as formas de arte popular britânicas. Apesar de seu propalado discurso em defesa dos excluídos e marginalizados, são acusados de manterem-se enredados numa tradição que persiste ligada à supremacia da cultura e da civilização ocidental. Além disso, apesar de 
se ocuparem de questões da classe trabalhadora, das mulheres, dos negros e outras minorias, eram presunçosa e exclusivamente homens brancos de classe média que militavam nesse empreendimento inicial.

Este criticismo permite situar alguns impasses na constituição do que é identificado por Hall (1996) como o legado teórico dos estudos culturais. ${ }^{11} \mathrm{De}$ acordo com a visão deste pesquisador, expressa no trabalho mencionado, não se trata de comentar o êxito ou a utilidade dos distintos posicionamentos teóricos, e sim, de discutir questões que dizem respeito ao relacionamento entre teoria e política. Os EC podem ser tomados como uma formação discursiva no sentido foucaultiano. Eles "abarcam discursos múltiplos bem como numerosas histórias distintas. Compreendem um conjunto inteiro de formações, com as suas diferentes conjunturas e momentos no passado. [...] foram construídos por metodologias e posicionamentos teóricos diferentes, todos confrontando-se entre si” (p. 263). Para Hall, os embates dentro dos EC foram cruciais para testá-los nas arenas culturais de um mundo moderno que se esvai e de novas ordens que se instalam.

As aproximações iniciais com uma prática crítica marxista demonstraram, desde o início, argumenta Hall (idem), os desencaixes, pois era evidente sua insuficiência para dar conta de questões que eram objeto privilegiado dos EC, como cultura, ideologia, a linguagem e o simbólico. Além disso, a ortodoxia, o caráter doutrinário, o determinismo, o reducionismo, a imutável lei da história, o estatuto de metanarrativa e um inequívoco eurocentrismo seriam também incongruentes com boa parte do que já se pensava e pretendia naquele momento (décadas de 1950 e 1960). Envolver-se com o marxismo significou mergulhar em um problema. A uma certa altura, o que se fez no Centro de Estudos Culturais Contemporâneos de

${ }^{11}$ Uma versão em português deste texto está publicada na Revista de Comunicação e Linguagens, do Centro de Estudos de Comunicação e Linguagens da Universidade Nova de Lisboa.
Birmingham, ${ }^{12}$ durante cinco ou seis anos, foi estudar tradições de pensamento que teriam contribuído para forjar o marxismo com o objetivo de procurar superar os limites que ele impunha. Quando o próprio Hall se aproximou da obra de Gramsci, isto teria se dado na medida em que o pensador italiano procurava saídas àquilo que a teoria marxista não respondia. E, nesse sentido, Hall não deixa de destacar o quanto a contribuição de Gramsci foi importante no que diz respeito à discussão de algumas questões que interessam ao estudo da cultura, despontando, entre elas, a extremamente produtiva metáfora da hegemonia. (Hall, 1996, p. 267).

Sob a ótica de Johnson (1999), apesar da crítica ao velho marxismo ter sido uma constante, tanto nas vertentes literárias quanto nas vertentes históricas dos $\mathrm{EC}$, há inegáveis contribuições:

A primeira é que os processos culturais estão intimamente vinculados com as relações sociais, especialmente com as relações e as formações de classe, com as divisões sexuais, com a estruturação racial das relações sociais e com as opressões de idade. A segunda é que cultura envolve poder, contribuindo para produzir assimetrias nas capacidades dos indivíduos e dos grupos sociais para definir e satisfazer suas necessidades. E a terceira, que se deduz das outras duas, é que a cultura não é um campo autônomo nem externamente determinado, mas um local de diferenças e de lutas sociais. (p. 13)

Com esta afirmação, Johnson recupera a importância das contribuições do marxismo, concordando com Hall, em que os elementos do marxismo, embora vivos e valiosos, precisam ser constantemente criticados, retrabalhados e testados em estudos detalhados. E é isto que acontece até os nossos dias.

12 Trata-se do Center for Contemporary Cultural Studies, sediado na Escola de Birmingham, na Inglaterra, onde os Estudos Culturais teriam emergido, na década de 1960, como prática intelectual institucionalizada. 
Outro embate importante nos EC diz respeito aos ataques advindos do movimento feminista e das lutas contra o racismo (Hall, 1996; Johnson, 1999). Essa expressão - ataque - caracteriza o sentido e os contornos dessa movimentação relativamente aos EC na década de 1970.

Segundo Hall (1996, p. 269), o caráter sexuado do poder tornou-se evidente quando, em virtude do expressivo crescimento e importância do movimento feminista no cenário dos anos de 1960 e 1970, o grupo masculino majoritário do Centro de Birmingham pensava que estava na hora de incorporar um bom trabalho feminista nos EC. Contudo, as mulheres invadiram o campo dos EC de forma intempestiva, repudiando qualquer promoção masculina relativamente ao seu ingresso. Isto, diz Hall, foi uma experiência inusitada, inesperada e radicalmente diferente, que o confrontava com a materialidade da noção foucaultiana de saber-poder. Em vez da planejada desistência do poder, os homens "transformados" e bonzinhos que abriam as portas às mulheres estavam sendo silenciados, tomados de assalto, contestados ruidosamente, além de expostos em suas ligações inequívocas com o arraigado poder patriarcal. Desde então, a crítica feminista nos EC tem produzido parte significativa das análises culturais que afetam os modos como as mulheres vêm ocupando espaços e sendo reposicionadas nas políticas culturais. ${ }^{13}$

No que diz respeito à questão racial, as lutas internas nos EC não foram diferentes. Os estudos, hoje numerosos e vicejantes, sobre questões críticas de raça e racismo, são resultantes de um longo, amargo e contestado combate interno contra um silêncio retumbante

${ }^{13}$ A manifestação mais contundente desta revolução feminista dentro dos EC, teria sido a publicação Women take issue, que em inglês é um trocadilho linguístico de duplo sentido. Significa tanto o número ou edição de uma publicação, indicando, neste caso, que as mulheres se apossaram da publicação da revista do Centro de Birmingham, como também take issue quer dizer discordar, referindo-se, assim, ao fato de que as intelectuais feministas introduziram suas vozes discordantes nos EC (Hall, 1996). e prolongado em torno desse ponto. Para Hall (1996), isto pode ser melhor compreendido se situado numa conjuntura arraigadamente britânica, e a retardada saída deste impasse tem conexões com as renhidas lutas da Nova Esquerda e suas discordâncias com o marxismo. Aqueles que se empenharam em produzir estudos voltados para esta questão enfrentaram imensa dificuldade para criar o espaço teórico e político necessário ao desenvolvimento desse projeto. ${ }^{14}$

Outro campo polêmico, em ebuliçãa desde os primórdios dos EC, é aquele constituído pelo que tem sido criticamente denominado de ortodoxia teórica do textualismo. Hall (1996) ressalta as repercussões da virada lingüística para os EC, com suas conseqüentes ênfases nas noções de discurso e texto, tomados agora em seu caráter produtivo e constitutivo da experiência cotidiana, das visões de mundo e das identidades. Segundo ele, também em relação a este tópico travou-se uma luta interna nos EC britânicos, cujos desdobramentos certamente legaram um saldo positivo tanto em termos de debates teóricos e compreensão da teoria quanto no que diz respeito à produtividade destas noções nas problematizações da cultura. O confronto nada tranqüilo entre trabalhos de cunho estruturalista, semiótico e pós-estruturalista, bem como os embates entre estes e as tradições de pensamento de vários matizes que inspiravam as análises do campo, não impedem, contudo, que se deixe de reconhecer:

A importância crucial da linguagem e da metáfora lingüística para qualquer estudo da cultura; a expansão da noção de texto e textualidade, seja como fonte de significado, seja como aquilo que elide ou adia o significado; o reconhecimento da heterogeneidade, da multiplicidade dos significados, do esforço envolvido no fechamento arbitrário da semiose infinita para além do significado; o reconhe-

${ }^{14}$ Os livros Policing the crisis: 'mugging', the state and law and order, editado por S. Hall, C. Critcher, J. Clarke e B. Roberts, em 1978, e The Empire strikes back, editado pelo Centro de Birmingham, em 1982, expressam as movimentações desta crise interna cujo foco eram as discussões sobre raça. 
cimento da textualidade e do poder cultural, da própria representação, como sítio de poder e de regulamentação; do simbólico como fonte de identidade. (Hall, 1996, p. 271)

Hall argumenta ainda que as consequiências da virada lingüística para os EC far-se-ão sentir ainda por longo tempo, reconfigurando as teorias, por ser preciso, agora, "pensar as questões da cultura através das metáforas da linguagem e da textualidade” (p. 271). Isso representa um adiamento necessário, um deslocamento inevitável, pois há sempre algo que escapa, descentrado, perdido no meio da cultura, na linguagem, nos textos, nos discursos, na significação, e esse algo pode ser o elo para localizar uma fonte de poder, aquilo que produz o significado a favor ou contra tal ou qual política.

Quando se assume que a cultura opera através das suas textualidades, o grande desafio de um projeto político como o dos EC, que "tenta desenvolver-se como uma espécie de intervenção teórica coerente" (idem, ibidem), é conseguir um registro teórico que dê conta disto. Parece que a saída é aprender a viver em uma tensão constante, testando permanentemente a vitalidade das teorias em confrontos com as materialidades de suas práticas cotidianas. Viver nessa tensão é o preço de não abdicar de pretensões intervencionistas. A exclusiva prática intelectual é tranqüila. Atribulada, incerta, instável e cambiante é a prática intelectual como política.

Tudo isso faz com que seja muito difícil, senão impossível, chegar-se a alguma precisão ou consenso relativamente a uma caracterização dos Estudos Culturais. Eles são muitas coisas ao mesmo tempo, tensionando os panoramas intelectuais e acadêmicos em que estão implicadas tanto as velhas e consagradas disciplinas como os movimentos políticos, práticas acadêmicas e modos de investigação tais como o marxismo, o pós-colonialismo, o feminismo, o pós-estruturalismo. Esse é o motivo pelo qual são freqüentemente descritos como uma antidisciplina ou pós-disciplina.

Hall (1996) diz que, apesar de o projeto dos EC caracterizar-se pela abertura, recusar-se a ser uma metanarrativa ou um metadiscurso, ou consistir num pro- jeto aberto ao desconhecido, ao inominável, não se pode reduzi-lo a um pluralismo simplista. De acordo com Sardar e Van Loon (1998), toda esta dificuldade para definir os Estudos Culturais não significa que "qualquer coisa pode ser estudos culturais, ou que estudos culturais podem ser qualquer coisa" (p. 9). Há, segundo estes dois autores, pelo menos cinco pontos distintivos dos EC. O primeiro é que seu objetivo é mostrar as relações entre poder e práticas culturais; expor como o poder atua para modelar estas práticas. O segundo é que desenvolve os estudos da cultura de forma a tentar captar e compreender toda a sua complexidade no interior dos contextos sociais e políticos. O terceiro é que neles a cultura sempre tem uma dupla função: ela é, ao mesmo tempo, o objeto de estudo e o local da ação e da crítica política. O quarto é que os EC tentam expor e reconciliar a divisão do conhecimento entre quem conhece e o que é conhecido. E o quinto, finalmente, refere-se ao compromisso dos EC com uma avaliação moral da sociedade moderna e com uma linha radical de ação política.

\section{Os Estudos Culturais na América Latina ${ }^{15}$}

Alasuutari (1999) faz referência ao "carisma dos estudos culturais", que teriam se espalhado por quase todo o mundo, e procura caracterizá-los da seguinte forma: "Eles têm crescido e se expandido não simplesmente através das pessoas que trabalham adotando os conceitos da Escola de Birmingham, mas principalmente porque essas pessoas se identificam com os EC"(p. 92, grifos nossos). Neste sentido - o da identificação de sujeitos e grupos de diferentes países com a atmosfera intelectual e as propostas investigativas dos EC - certamente têm atuado algumas condições marcantes da pós-modernidade, como as

15 Nesta seção, entenderemos os estudos culturais latinoamericanos como aqueles que são desenvolvidos apenas na América de língua espanhola, excluindo-se o caso brasileiro. De certa forma, adotando-se uma perspectiva que simboliza o mútuo distanciamento em que os dois contextos têm atuado. 
instabilidades do mundo contemporâneo, a desintegração das narrativas mestras que o explicavam, as inúmeras rupturas com a ordem estabelecida, a intensa conexão planetária favorecida pela mídia, as novas questões trazidas por inéditas formas de migração e desterritorialização, condições às quais os EC parecem corresponder, produzindo encaixes temporários, porém fecundos.

Inúmeros países têm "ancorado" EC, ${ }^{16}$ e isto não se deve, necessariamente, a uma migração dos EC britânicos. Parece que as conexões entre os estudos que revolucionam a teoria cultural contemporânea podem ser atribuídas, primordialmente, à amplitude e abrangência destas movimentações no cenário de um mundo que se torna transparente. A expressão "sociedade transparente", utilizada por Gianni Vattimo (1991) para atribuir sentido ao pós-moderno, diz respeito ao fato de vivermos em uma sociedade de comunicação generalizada, massificada, onde tudo se torna visível, de variados ângulos e sob inúmeras versões. Segundo o autor, o desenvolvimento vertiginoso das tecnologias da comunicação e da informação - jornais, rádio, televisão, informática e afins estaria associado às crises do colonialismo e do imperialismo europeu, e teria contribuído radicalmente para a dissolução de pontos de vista centrais, tornado impossível a manutenção de uma concepção de história como curso unitário em direção ao progresso.

Os Estudos Culturais na América Latina têm sido marcados simultaneamente por um grande florescimento e uma não menos expressiva quantidade de po-

${ }^{16}$ Numa cartografia dos EC, estes teriam migrado, nos anos de 1980 e 1990, para Austrália, Canadá e Estados Unidos, mencionados como aqueles países onde há maior difusão. Também França, Espanha, Nova Zelândia, Índia e países do sul da Ásia fazem parte deste mapa. A esse respeito ver Sardar e Van Loon (1998), Costa (2000b). Há discordâncias sobre as direções e as origens deste fluxo, conforme comentamos no presente artigo. Uma cartografia dos EC na América Latina é objeto da pesquisa de Escosteguy (2001). lêmicas, críticas e negações de sua legitimidade, sua relevância e seu status acadêmico. A existência, facilmente comprovável por incursões na Internet, de centros universitários e de pesquisa, e de programas de mestrado e doutorado que focalizam os Estudos Culturais (ou, mais freqüentemente, os Estudios Culturales Latinoamericanos) sinaliza tal florescimento, indicando que no Chile, na Argentina, no México, na Colômbia, no Equador, na Venezuela, no Uruguai, por exemplo, há um conjunto - ou mais, ou menos expressivo - de reflexões, estudos e iniciativas institucionais que se filiam a esses estudos.

Mesmo que sua história ainda esteja por ser escrita, ${ }^{17}$ conforme assinala Moreiras (2001, p. 355), é possível, através de um sobrevôo por suas temáticas, características e principais questões, esboçar um quadro que nos ajude a ver as formas pelas quais - em sua especificidade - eles podem ser (e têm sido, como veremos adiante) inspiradores para as reflexões em educação no espaço latino-americano.

As polêmicas iniciam pela circunscrição do que "pertenceria" aos Estudos Culturais e o que não seria específico do campo, já por si só caracterizado como teórica e metodologicamente instável. De forma paradoxal, os nomes mais constantemente associados aos Estudos Culturais na América Latina - Néstor García Canclini, Jesús Martín-Barbero e Beatriz Sarlo - não são intelectuais que se reconheçam alinhados ou se filiem aos EC de maneira inconteste. Efetivamente, os EC capitalizaram e renomearam estudos de "análise cultural" que se faziam na América Latina anteriormente, influenciando o seu desenvolvimento, como afirmam, inclusive, os dois primeiros nomes citados anteriormente. Martín-Barbero, por

\footnotetext{
${ }^{17}$ Para um exame dos estudos de comunicação e cultura na
} América Latina, focalizando especificamente Martín-Barbero, Néstor García Canclini e, como referência, Stuart Hall, ver Escosteguy (2001); para ter acesso a um debate sobre as relações entre estudos literários e estudos culturais na América Latina, dentro de um quadro mais amplo que envolve pensar questões históricas, filosóficas e regionais, ver Moreiras (2001). 
exemplo, declara, em entrevista prestada à revista eletrônica Dissens em 1996:

Não comecei a falar de cultura porque me chegaram coisas de fora. Foi lendo Martí, ${ }^{18}$ Arguedas ${ }^{19}$ que eu a descobri, e com ela os processos de comunicação que se tinha de compreender. [...] Nós havíamos feito estudos culturais muito antes de que essa etiqueta aparecesse.

Também Canclini, conforme Mato (2001, p. 1), teria afirmado que havia começado a "fazer Estudos Culturais" antes de se dar conta de que eles assim se chamavam. Nomeações à parte, é importante assinalar que a década de 1990 é reconhecida como a década em que ocorreu a explosão dos EC na América Latina, marcada pela realização de pesquisas sobre “consumo cultural”, ora utilizando metodologias quantitativas, ora estratégias qualitativas (entrevistas e dinâmicas de grupo, por exemplo), expandindo-se por meio de estudos e publicações de ensaios de maior fôlego. Cabe registrar, ainda, no que diz respeito aos EC da América Latina, a freqüente utilização das expressões “Teoria cultural” e "análises culturais", numa superposição que torna difícil falar de fronteiras e limites rígidos em relação ao que se vem entendendo por Estudos Culturais.

${ }^{18}$ José Martí, poeta, ensaísta e jornalista cubano, nascido em 1853 e morto em 1895, é considerado o maior herói da luta pela independência de Cuba contra a Espanha e um dos maiores escritores do mundo hispânico. Sua multifacetada experiência intelectual e formação educativa permitiram uma movimentação teórica nos mais diversos campos, o que o tornou uma voz influente no pensamento latino-americano.

${ }^{19}$ José Maria Arguedas, escritor e antropólogo peruano, nascido em 1911 e morto em 1969, adquiriu importância como novelista, tradutor e, também, como antropólogo preocupado com as questões da cultura andina de origem quéchua, seu confronto e mestiçagem com a cultura peruana urbana de raízes européias. Freqüentemente citado pelos autores mais recentes dos EC latinoamericanos, parece ter sido influência marcante no pensamento cultural latino-americano.
Nesse sentido, se há consenso acerca da explosão dos EC na América Latina dos anos de 1990, é necessário recuar no tempo para rastrear o contexto peculiar em que eles foram gestados. Para Ríos (2002, p. 247), os EC latino-americanos podem ser definidos como "um campo de estudos configurado dentro da tradição crítica latino-americana", e, ainda que tenham significado uma ruptura epistemológica com o que antes se fazia, inserem-se em uma importante tradição do ensaio de idéias da América Latina, tradição esta que já vinha se estabelecendo desde o século XIX. Além disso, há que se citar a efervescência do panorama cultural nas décadas mais recentes, em muitos países latino-americanos, como relembra oportunamente Mato (2001, p. 13), alertando para que não percamos de vista

[...] a importância, para o campo dos estudos e outras práticas em cultura e poder, das contribuições de Paulo Freire, Orlando Fals Borda, Aníbal Quijano e numerosos intelectuais latino-americanos que mantiveram e mantêm práticas dentro e fora da academia e que, portanto, não necessariamente fazem "estudos", assim como dos diversos movimentos teatrais e ativistas teatrais (os casos de Augusto Boal e Olodum, por exemplo), o movimento zapatista no México, os movimentos e intelectuais indígenas em quase todos os países da região (mas particularmente em Chile, Bolívia, Equador, Colômbia e Guatemala), o movimento feminista, o movimento dos direitos humanos, diversos movimentos de expressões musicais (a nova canção, os rocks críticos, etc), o trabalho de numerosos humoristas (Quino, Rius, Zapata e outros) e de cineastas (novo cinema brasileiro e outros, etc.).

Se a questão das fronteiras e dos contextos que constituíram condições de possibilidades para a eclosão dos EC latino-americanos é um campo aberto para múltiplas explorações, também avultam as discussões ligadas à sua nomeação. Assim, uma de suas denominações - Latin American Cultural Studies - é objeto de discussão e contestação. Mato (2001, p. 6) entende que tal denominação os situaria nos chamados Area Studies, os quais, em sua origem, estariam associados 
a projetos imperiais de produção de conhecimentos sobre povos e nações dominados, conhecimentos esses produzidos para uso das metrópoles. $\mathrm{O}$ autor venezuelano entende que é na academia estadunidense que tem se estabelecido o cânone "válido" para os EC latino-americanos, com a sacralização de alguns autores e a consagração de uma leitura específica dos mesmos; além disso, ele expressa seu temor em relação ao que identifica como uma influência despolitizadora dos EC estadunidenses, em tópico que adiante retomaremos.

Com que dosagem os diferentes elementos da química geradora dos EC latino-americanos - a influência dos EC britânicos, estadunidenses e australianos, por um lado, uma tradição latino-americana anterior e concomitante de ensaios críticos e análises culturais, por outro - se misturaram, e com quais "resultados", não é questão fácil de responder e nem é esta aqui nossa pretensão. Entende Moreiras (2001) que "tal história também tem uma genealogia totalmente diferente, bem como condições distintas de inscrição social e intelectual" (p. 355), o que se reflete, por exemplo, em alguns temas recorrentes e diferentes negociações que os trabalhos latino-americanos farão com trabalhos de outras áreas. Como bem assinalaram Canclini e MartínBarbero (apud Mato, 2001), o encontro entre aportes e leituras dos EC, as tradições de estudo anteriores e novas vertentes investigativas constituíram um sítio interessante para novas e instigantes produções, mesmo que sobre elas possa recair o estigma de algum sincretismo teórico e metodológico.

Em contrapartida, há que se sublinhar que, a diferença dos EC britânicos, estadunidenses e australianos, em que a circulação de textos dos diversos autores não sofreu qualquer constrangimento advindo da língua utilizada na escrita, no panorama latino-americano a questão dos idiomas que os intelectuais dominem ou não, não é uma questão menor no panorama da legitimação e disseminação do que seriam os "genuínos" EC. Mignolo (apud Mato, 2001, p. 10) observa que "o espanhol e o português são idiomas que caíram do carro da modernidade e se converteram em idiomas subalternos da academia". Isso explicaria um maior sucesso daqueles acadêmicos que, geralmente em função de cursos de pós-graduação e bolsas de estudo, exibem um significativo domínio da língua inglesa, idioma em que, por exemplo, é publicado o conhecido periódico denominado Latin American Cultural Studies. Interessante notar que - se se entende a língua como um importante marcador de identidade - um dos temas mais caros aos EC da América Latina - tal questão poderia ser considerada central à própria discussão interna dos grupos de Estudos Culturais latino-americanos, o que efetivamente não parece vir ocorrendo.

De forma similar à sua ação em outros continentes, também na América Latina os EC vêm colaborando para a implosão das linhas acadêmicas de separação das áreas disciplinares. Castro-Gómez (2000, p. 157) afirma, por exemplo, que "a vocação transdisciplinar dos estudios culturales tem sido altamente saudável para algumas instituições acadêmicas que, pelo menos na América Latina, tinham se acostumado a 'vigiar e administrar' o cânone de cada uma das disciplinas”. Para Moreiras (2001, p. 74), “as disciplinas mais seriamente afetadas pela ascensão dos estudos culturais hoje" são os estudos literários, a história, a antropologia e os estudos da comunicação. Em entrevista concedida em 1994 (Canclini, 1997b, p. 79), Canclini registra a origem disciplinar diferenciada dos primeiros pesquisadores dos EC da América Latina, afirmando:

Creio que essa corrente de estudos é proveitosa no sentido de que é gerada de uma variedade de diferentes disciplinas: Brunner, da sociologia, Martín-Barbero, da comunicação e semiótica; meu próprio background é em filosofia, mas também sociologia, crítica da arte e antropologia; Sarlo, dos estudos literários, e Ortiz, antropologia e sociologia. Penso que o que temos em comum é o desejo de encontrar uma maneira melhor de estudar os processos culturais de uma forma multidisciplinar. Combinar tais abordagens é central ao projeto, uma vez que entendamos processos culturais como processos que devem ser problematizados mais como interconectados e interdependentes do que como fenômenos isolados, que é a forma como são tratados na maioria das disciplinas. 


\section{Temáticas preferenciais dos Estudos Culturais na América Latina}

Como vimos, os Estudos Culturais realizados na América Latina foram impregnados pelos contextos, problemáticas e tensões vividas nos diferentes grupos e nações do continente, vindo a mesclar-se com estudos anteriores que, de certa forma, foram revigorados. Para Ríos (2002, p. 247), como os EC se ocupam da produção simbólica da realidade social latino-americana (materialidade, produções e processos),

[...] qualquer coisa que possa ser lida como um texto cultural e que contenha em si mesma um significado simbólico sócio-histórico capaz de acionar formações discursivas, pode se converter em um legítimo objeto de estudo: desde a arte e a literatura, as leis e os manuais de conduta, os esportes, a música e a televisão, até as atuações sociais e as estruturas do sentir.

Nesse sentido, pode haver uma especificidade como efetivamente há - em muitos estudos da vertente latino-americana, mas - vistos em sua globalidade eles se harmonizam com o desenvolvimento mais global do campo, que se propõe multitemático e polifonicamente interessado em quaisquer artefatos, processos e produtos que "signifiquem".

A contestação da diferença entre a "alta cultura" e a "baixa cultura" que caracterizou tão profundamente o campo desde o seu surgimento pode ser comparada, por exemplo, às análises que Canclini realiza das fronteiras entre "arte" e "artesanato". Enveredando pelas vielas do consumo, da produção dos chamados artistas populares e da mercantilização das tradições, que se situam na arena da peculiar "modernidade" da América Latina, Canclini observa o quanto, a um olhar "refinado" tradicional, a linha que separa a arte do artesanato popular é traçada conforme as oposições dos cânones tradicionais do "culto e popular": a arte é vista como "movimento simbólico desinteressado, um conjunto de bens 'espirituais' nos quais a forma predomina sobre a função e o belo sobre o útil", enquanto "o artesanato aparece como o outro, o reino dos objetos que nunca poderiam dissociar-se de seu sentido prático" (Canclini, 1998, p. 242); a arte, como produzida por artistas "singulares e solitários", o artesanato, por populares "coletivos e anônimos"; a arte, como referente a "obras únicas, irrepetíveis"; o artesanato, como referente a "objetos em série", reiterativos em suas estruturas. Submetendo tais oposições a uma informada e aguda crítica, o autor latino-americano questiona cada um desses parâmetros diferenciadores, e observa - numa afirmação que, de certa maneira, estampa uma diretriz constante e definidora do seu trabalho: Seria possível avançar mais no conhecimento da cultura e do popular se se abandonasse a preocupação sanitária em distinguir o que teriam a arte e o artesanato de puro e não-contaminado e se os estudássemos a partir das incertezas que provocam seus cruzamentos (idem, p. 245).

Este é, apenas, um pálido exemplo da pujança das análises que incidem sobre questões culturais da América Latina. As hibridações - o importante conceito proposto por Canclini para a análise das culturas latino-americanas, as identidades e sua fragmentação, as redes de dependências, as relações entre tradição e modernidade, as transformações das culturas populares, os consumos culturais são alguns dos núcleos temáticos mais poderosos que deram e dão fôlego ao pensamento latino-americano nomeado como EC ou lindeiro a esses.

Entre os traços comuns à maioria de tais estudos, avulta uma insistente referência às transformações da América Latina, nas últimas décadas, como decisivas para a modelagem das temáticas, metodologias e focos de tais pesquisas. São recorrentes as alusões a mudanças políticas (à derrocada dos governos militares, mais freqüentemente, com conseqüente abertura de processos de democratização), ao surgimento dos blocos econômicos (como Mercosul, por exemplo), ao declínio dos Estados-nação e de outras instituições tradicionais (religião, escola) como referentes para a identidade, ao mesmo tempo em que se alude à crescente e avassaladora presença da mídia em todos os estratos da população, às transformações do lugar da mulher no âmbito público e privado latinoamericano, a questões como a das populações indíge- 
nas e mudanças de enfoque de sua problemática, assim como a atenção a atores sociais com relevância cultural mais recentemente atribuída, como é o caso dos jovens, isso, sem falar nas novas preocupações com as questões urbanas, entendendo-se as cidades como sítios privilegiados da produção de significados culturais no fim do século XX e início do XXI.

Nesse sentido, um projeto levado a efeito pelo Centro de Estudios Culturales da Universidade do Chile, cujo delineamento encontra-se disponível na Internet, ${ }^{20}$ é exemplar pela riqueza de sua trama conceitual e caráter revisor das questões que têm preocupado os EC da América Latina. Denominado Identidades en América Latina: discursos y prácticas, o projeto, contando com uma equipe multidisciplinar, coloca questões que - descontada sua particularização à nação chilena - poderiam ser entendidas como atravessando em grande escala os EC latino-americanos. São elas: Quais são os atuais discursos que sustentam e/ou fraturam as identidades no Chile? Que identidades articulam e expressam? Que identidades excluem? Quais são suas coordenadas epistêmicas, éticas e sócio-históricas? Quais são seus espaços de produção e circulação? Quais são seus dispositivos, estratégias e políticas culturais?

Explorando um pouco a potencialidade de tais questões, confrontadas com a pujante produção dos EC latino-americanos, poder-se-ia enfatizar o lugar do "indígena" na questão das identidades latino-americanas como um dos grandes eixos inspiradores de trabalhos, assim como, já do ponto de vista da área da Comunicação, a questão do consumo cultural dos produtos da mídia. Tanto uma como outra questão se confrontam na tensão global $x$ local, também presente em significativo número de obras "fundadoras" e estudos acessíveis ao leitor brasileiro. ${ }^{21}$

Em relação ao primeiro tópico, perspicazes análises sobre a impossível pureza do indígena (expressão

${ }^{20}$ Disponível em: <http://www.uchile.cl/facultades/filosofia/ cestculturales/proyecto2.html>. Acesso em: 29 mar. 2003.

${ }^{21}$ Correndo o risco de reiteração, vale a pena relembrar obras básicas como Consumidores e cidadãos e Culturas híbridas, de de Martín-Barbero) são levadas a efeito por vários autores, como os já citados Sarlo, Canclini e MartínBarbero. Contrapondo-se às visões românticas que viam no índio o "único traço que nos resta da autenticidade", o "lugar secreto onde subsiste e se conserva a pureza de nossas raízes culturais" (Martín-Barbero, 1997a, p. 260), o estudioso procura pensá-lo dentro do espaço político e teórico do "popular", nem visto como externo ao desenvolvimento capitalista, nem como simples molusco engolido por sua voragem. Nessa direção, as pressões exercidas pelo consumo, pelo mercantilismo, pelo discurso do exotismo e do rústico, dentro do cenário mais amplo de um turismo que é, principalmente, fonte de sobrevivência, não podem ser negadas nem demonizadas.

Enfim: tematicamente os EC da América Latina têm mergulhado nos processos e artefatos culturais de seus povos, na cotidianidade das suas práticas de significação, na contemporaneidade de um tempo em que as fronteiras entre o global e o local se relativizam, se interpenetram e se modificam. Um exame dos sumários de obras publicadas, seminários, jornadas e revistas que têm abrigado trabalhos de EC nos aponta uma variedade temática que congrega, por exemplo, dentro do campo mais amplo da cultura popular urbana, a questão das culturas dos bairros populares, os graffiti, a apropriação e a reelaboração musical, o rock e as subculturas juvenis etc. Conforme Follari (2000, p. 5), encontramos, nos EC da América Latina,

\footnotetext{
[...] textos de uma capacidade previamente insuspeitada para amplificar o olhar sobre o mundo do microssocial e dos fenômenos de constituição e modificação das identidades; sobre as modalidades de agrupamento e de associação; sobre os procedimentos de produção e de consumo cultural; sobre a invenção das tradições e configuração da autocompreensão promovidas pelos estados nacionais.
}

Néstor García Canclini, Cenas da vida pós-moderna e Paisagens imáginárias, de Beatriz Sarlo, e Dos meios às mediações: comunicação, cultura e hegemonia, de Jesús Martín-Barbero, todas traduzidas para o português. 


\section{Algumas discussões - os Estudos Culturais na América Latina e a pós-modernidade}

Por outro lado, uma questão como as relações entre os EC e a pós-modernidade também está no fulcro dos debates, uma vez que - em certos círculos os Estudos Culturais teriam aparecido como "o âmbito específico e exclusivo da discussão relativa ao tema pós-modernidade - ao menos para muitos analistas teóricos e grupos de leitores" (idem, p. 2). Em interessante discussão sobre a presença ou ausência das discussões mais filosóficas da pós-modernidade dentro dos EC realizados na América Latina, o citado autor $(2000)^{22}$ observa que não encontra dentro dos mesmos uma discussão aprofundada ou demorada, de cunho filosófico, sobre a pós-modernidade. Para usar suas palavras:

[...] nada disso [referências a Nietzsche, Heidegger, Derrida, Vattimo, Baudrillard, Lipovetski] aparece nos estudos culturais e isso é simplesmente porque esses últimos são estudos do que há no pós-moderno, mas não "sobre” o pósmoderno. São estudos sobre identidades, sobre comunicação, sobre teoria literária e sua relação com a cultura ou sobre os modos de constituição do nacional ou do internacional/compartilhado. Porém seu objeto explícito não é o moderno/pós-moderno, mas a cultura contemporânea, a qual está, obviamente, atravessada pelos efeitos da passagem do moderno ao pós-moderno. (p. 7)

O referido autor efetua um detido exame das superposições, encontros e desencontros das reflexões sobre a pós-modernidade e as realizadas pelos EC na América Latina. Para ele, "o pós-moderno não se entende sem os Estudos Culturais nem se entende somente com eles", assinalando também a fecundidade das temáticas que os EC trouxeram para exame, temáticas que não haviam aflorado em autores "filosóficos". As

${ }^{22}$ Roberto Follari é professor titular de epistemologia das ciencias, na Facultad de Ciencias Políticas y Sociales, Universidad Nacional de Cuyo, província de Mendoza (Argentina). temáticas do tempo presente, como a bastante explorada questão da cultura juvenil, das bandas de rock, do fanatismo esportivo, ou da música salsa, trazidas à boca de cena pelos estudos culturais (embora não apenas por estudos que, nominalmente, se filiem a eles) na América Latina, revitalizaram a reflexão sobre as contingências, articulações e buscas de compreensão da pós-modernidade em nosso continente.

Em contrapartida, alguns desenvolvimentos "filosóficos" relativos à pós-modernidade que cobrem importantes aspectos teóricos, como o status do pósmoderno, a relação com a modernidade, com o modernismo, com a modernização, com as temáticas do sujeito e das ciências, ou não são tematizados nos trabalhos de EC ou o são apenas de passagem (Follari, 2000, p. 6). Para o autor, efetivamente se observa uma certa exterioridade de cada campo em relação ao outro - um se debruçando sobre a cultura do pós-moderno e outro propondo uma teorização específica sobre a pós-modernidade; ultrapassar tal alheamento mútuo, observa ele, ensejaria um "mútuo fecundamento conceitual".

Alguns questionamentos relativos aos EC na América Latina parecem advir justamente do entendimento de que eles deveriam propor um entendimento universalizante, ou melhor, parecem resultar da percepção do visceral enlace dos EC com os discursos da fragmentação e relativismo típicos da pós-modernidade. Neste sentido, vale a pena dar voz às inquietações de Canclini (1997a):

Quando menciono paradigmas ou modelos não estou regressando ao cientificismo que postulava um saber de validade universal, cuja formalização abstrata o tornaria aplicável a qualquer sociedade e cultura. Mas tampouco me parece satisfatória a complacência pós-moderna que aceita a redução do saber a narrativas múltiplas. Não vejo por que abandonar a aspiração de universalidade do conhecimento, a busca de uma racionalidade interculturalmente compartilhada que dê coerência aos enunciados básicos e os contraste empiricamente. Foi esse tipo de trabalho que colocou de forma clara que diferentes culturas possuem lógicas e estratégias diferentes para ter acesso ao real e validar seus 
conhecimentos, mais intelectuais em alguns casos, mais ligadas à sensibilidade" e à "imaginação" em outros.

De certa maneira, as preocupações citadas anteriormente - que certamente ecoam entendimentos modernos de conhecimento - vão se articular, no desenvolvimento da argumentação de Canclini, a preocupações que se conectam com o caráter político dos EC, em que o próprio autor será objeto de ataques. Acompanhemos sua exposição, em que o apelo à racionalidade (moderna?) também se faz presente:

Creio que o relativismo antropológico que fica em um reconhecimento desierarquizado de tais diferenças mostrou limitações suficientes para que nele nos instalemos. A necessidade de construir um saber válido interculturalmente se torna mais imperiosa em uma época em que as culturas e as sociedades se confrontam todo o tempo nos intercâmbios econômicos e comunicacionais, nas migrações e no turismo. Precisamos desenvolver políticas cidadãs que se baseiem em uma ética transcultural, sustentada por um saber que combine o reconhecimento de diferentes estilos sociais com regras racionais de convivência multi-étnica e supranacional. (idem, ibidem)

Efetivamente, coexistem no pensamento deste que é um dos mais importantes autores dos EC latino-americanos ${ }^{23}$ a constante busca de negação de certos eixos da compreensão moderna de mundo - a negação das totalidades marxistas, por exemplo - com a procura de um ponto de sustentação que justifique

${ }^{23}$ Ainda que o exemplo citado seja o de Canclini, tais tensões são freqüentes em outros estudos de pesquisadores latinoamericanos; é impossível esquecer, nesse sentido, que expressivo número dos intelectuais da América Latina com produção nas áreas das ciências humanas militou e milita na crítica de esquerda às estruturas colonialistas, autoritárias e exploradoras de seus países; são esses mesmos ensaístas e acadêmicos que, ao produzirem análises culturais, não fogem (nem o querem) dos compromissos políticos - no sentido amplo - em que foram formados. não apenas análises culturais das diferenças, mas também a condenação das desigualdades tão manifestamente expostas na contemporaneidade da América Latina. De maneira mais geral ainda, Canclini (1997a, p. 2), em texto em que aborda o "mal estar dos estudos culturais", aponta como uma das fragilidades de seu desenvolvimento na América Latina a falta de uma mais consistente reflexão teórica e epistemológica, alertando para o risco de uma "aplicação rotineira de uma metodologia pouco disposta a questionar teoricamente sua prática" e sugerindo um esforço maior nesse sentido.

\section{O utra discussão: a despolitização da teoria e da pesquisa}

Também no caso dos Estudos Culturais latinoamericanos se fazem ouvir vozes que criticam a alegada renúncia ao caráter político do campo, mesmo que elas atinjam autores e obras que não tenham abandonado a intenção de uma ação política "transformadora". Tomando como exemplo um dos livros considerados centrais no campo - Consumidores $e$ cidadãos -, pode-se resgatar a crítica mais comum ao mesmo, a qual consiste na não-aceitação do nosso status de habitantes da contemporaneidade como meros consumidores em vez de legítimos cidadãos. Follari (2000, p. 2) aponta a leitura dessa obra e de outras dos EC latino-americanos vendo-as como cúmplices de um caráter "adaptacionista" dos Estudos Culturais. O slogan de Canclini, em Consumidores e cidadãos - "O consumo serve para pensar" - certamente foi um dos dispositivos motivadores de algumas dessas contestações. Já na via inversa dessa crítica à despolitização dos estudos culturais, Martín-Barbero propõe uma reflexão que ultrapasse os velhos cacoetes de uma esquerda apenas preocupada com as ações reivindicatórias dos grupos "oprimidos" e de suas ações de organização de classe, de uma esquerda que vê as práticas do viver cotidiano mais como um "obstáculo à tomada de consciência do que como ação política conseqüente" (Martín-Barbero, 1997a, p. 289). E assevera (p. 290): 
O consumo não é apenas reprodução de forças, mas também produção de sentidos: lugar de uma luta que não se restringe à posse dos objetos, pois passa ainda mais decisivamente pelos usos que lhes dão forma social e nos quais se inscrevem demandas e dispositivos de ação provenientes de diversas competências culturais.

Também é freqüente, em um continente onde o pensamento social frequientemente buscou força nos ditames marxistas e críticos, a emergência de um certo desconforto em relação ao abandono, pelos EC, de explicações ou totalizantes ou alinhadas ao discurso da "libertação". Nesse diapasão, Castro-Gómez (2000, p. 158), entendendo que a cultura urbana de massa e as novas tecnologias da informação têm sido vistas nos EC latino-americanos como "espaços de emancipação democrática”, levanta a suspeita de que os estudos culturais teriam "hipotecado seu potencial crítico à mercantilização fetichizante dos bens simbólicos". E mais: o crítico atribui aos EC latino-americanos um novo tabu - o da abordagem da "totalidade", seduzidos que estariam pela fragmentação do sujeito, pela hibridação das formas de vida, pela articulação das diferenças e pelo desencanto diante das novas metanarrativas. Não se trata, para o autor, de reabilitar as velhas dicotomias da teoria crítica - colonizador $x$ colonizado, centro $x$ periferia, opressor $x$ oprimido, centro $x$ periferia - mas, sim, de tornar visíveis os "novos mecanismos de produção das diferenças em tempos de globalização", através de uma "descolonização" das ciências sociais e da filosofia.

Outra inconformidade alinhada ao pretenso caráter despolitizante dos EC diz respeito à elisão do conceito de classe social, tão caro às teorias críticas. Verdesio (2003, p. 4) assim sintetiza tal crítica em relação aos mesmos:

A apropriação do popular [...] se deve, entre outras coisas, à incorporação a um modelo teórico que quer ver nelas [produções da cultura popular] uma confirmação, na maioria dos casos, da falácia seguinte: na pós-modernidade, por fim, os marginalizados podem se expressar. Entretanto, todas essas celebrações perdem de vista, sistemati- camente, as questões de classe. Quero dizer que os estudos culturais, em geral, tendem a deixar de lado qualquer análise de classe possível. E isto, em sociedades tão desiguais como as latino-americanas, se parece mais com um pecado do que com um erro de perspectiva.

De qual lado estariam os argumentos mais poderosos é uma questão cuja resposta dependeria de uma incursão mais demorada, inadequada às dimensões deste artigo.

\section{Apontamentos finais sobre Estudos Culturais na América Latina}

Em interessante entrevista dada por Canclini a Patrick D. Murphy (Canclini, 1997b), o autor argentino-mexicano traz algumas informações que podem enriquecer este breve esboço dos EC na América Latina. Uma das questões colocadas pelo entrevistador, com respeito à perspectiva feminista dentro dos EC da América Latina, é respondida por Canclini através da marcação da diferença entre o feminismo americano e os estudos sobre mulher na América Latina, além de reconhecer que, efetivamente, esse enlace poderia ser mais forte no caso dos EC latino-americanos. Com respeito às influências da Escola de Birmingham na formação dos EC do continente, Canclini a reconhece, em certa medida, nos estudos de comunicação, e também aponta a existência de outras fortes influências não diretamente associadas aos EC, como a de Pierre Bourdieu, cuja importância, diz Canclini, não tem sido oficialmente reconhecida. Por fim, quando questionado sobre diferentes leituras do pós-modernismo pelos escritores latino-americanos e pelos ensaístas clássicos, (como Jameson, Baudrillard e Lyotard), Canclini aponta algumas diferenças (Canclini, 1997b, p. 87):

Na América Latina um conjunto de distintas circunstâncias políticas impregna a articulação cultural; isto é, existem diferentes formas nas quais modos tradicionais de vida são articulados com os processos de modernização. A esse respeito, os escritores latino-americanos têm mostrado uma elevada sensibilidade para reconhecer formações culturais 
que não são necessariamente "modernas"; a memória popular é um importante elemento que contribui para a mudança das culturas contemporâneas.

As transações entre os EC dos países americanos de língua espanhola e o Brasil, exceção feita a Canclini, Martín-Barbero e Beatriz Sarlo, têm sido tímidas e incipientes, possivelmente em função de certas dificuldades históricas de tal relacionamento, por parte da intelectualidade brasileira, que, no caso específico, se tem abeberado nas leituras dos autores ingleses, americanos e australianos, ora lidos em traduções publicadas, ora em traduções "preliminares", ora no original. Mas a dificuldade de acesso à bibliografia latino-americana publicada nos diferentes países latino-americanos sobre EC também desempenha seu papel neste distanciamento; enquanto os lançamentos sobre EC em língua inglesa são pronta e expeditamente disponibilizados nas livrarias virtuais e grandes editoras de língua inglesa, idêntico sistema na América Latina é precário e, em alguns países, inexistente. Também a leitura de trabalhos latino-americanos de EC aponta para um tímido aproveitamento dos estudos brasileiros, exceção feita à produção de Renato Ortiz, celebrada pelos autores latino-americanos já citados.

Por fim, há que se assinalar que os EC não têm sido, na América Latina, apenas um manancial de estudos e de polêmicas; institucionalizados em grande medida, eles também já constituem "tema de cursos", inclusive na Internet. Nesta esteira, o Consejo Latinoamericano de Ciencias Sociales (CLACSO) programa para o ano de 2003 um curso à distância sobre "Los Estudios Culturales en Latinoamerica", do qual disponibiliza aos internautas interessados um plano de estudo, de que pinçamos um trecho por seu poder de síntese em relação ao campo cultural que é focalizado por tais estudos na América Latina (Los estudios, p. 2):

No nível de conteúdos temáticos, a cultura que os estudos culturais "criam” não é a mesma que haviam criado, anteriormente, a antropologia, a sociologia, a economia ou as humanidades. [...] A cultura que os Estudos Cul- turais "estudam" tem menos a ver com os artefatos culturais em si mesmos (textos, obras de arte, mitos, valores, costumes, etc) do que com os processos sociais de produção, distribuição e recepção desses artefatos. Ao mesmo tempo, os estudos culturais privilegiam o modo no qual os próprios atores sociais se apropriam desses imaginários e os integram a formas locais de conhecimento.

\section{Estudos culturais em educação: que território é este?}

A IV Conferência Internacional Crossroads in Cultural Studies, ${ }^{24}$ realizada em Tampere, na Finlân-

${ }^{24}$ Conforme dados do site www.tampereconference.fi/ crossroads.htm, as conferências assim denominadas iniciaram em 1996, em Tampere, e têm acontecido a cada dois anos para suprir uma lacuna na comunidade internacional dos Estudos Culturais. Embora os EC se tornem crescentemente internacionais e multicentrados - ou cada vez menos centrados por sua natureza virtual - as pessoas que neles atuam têm escassas oportunidades de se encontrarem face a face. Conferências e seminários têm acontecido ocasionalmente, mas circunscritos a temas e regiões. $\mathrm{O}$ clamor por uma conferência internacional advém desse caráter dos Estudos Culturais de serem um lugar de encontro, um cruzamento [crossroads] entre diferentes pessoas e disciplinas. A primeira conferência Crossroads in Cultural Studies assim definiu a finalidade desses eventos "Estudos Culturais não são uma via de mão única entre o centro e as periferias. Em vez disso, são um cruzamento, um lugar de encontro entre diferentes grupos, disciplinas e movimentos intelectuais. Pessoas em muitos países e com diferentes backgrounds traçaram independentemente suas trajetórias por estes cruzamentos. Elas fizeram contatos, intercambiaram pontos de vista e trocaram inspiração ao perseguirem seus objetivos. A vitalidade dos Estudos Culturais depende de um trânsito continuo através destes cruzamentos. Por esta razão os organizadores da Conferência convidam pessoas de diferentes orientações teóricas, disciplinas e geografias para juntos compartilharem suas idéias". A primeira Conferência (1996), a segunda (1998) e a quarta (2002) aconteceram em Tampere, na Finlândia. A terceira (2000) teve lugar em Birmingham, na Inglaterra, e a quinta (2004) se realizará em Urbana-Champaign, nos Estados Unidos. 
dia, em julho de 2002, com o propósito de ser um fórum aberto às temáticas que pudessem interessar a diversificada "comunidade" dos EC, apontou 21 tópicos de interesse ${ }^{25}$ para articular o amplo e aberto debate com a participação de pesquisadoras e pesquisadores de vários países. Entre estes, constava aquele que é nosso principal foco de atenção neste artigo - Estudos Culturais, Educação e Pedagogia - sendo apresentadas várias propostas de painel para discussão de questões específicas relativas ao tema. Uma delas intitulavase Cultural Studies and/in/as Education (Estudos Culturais e/em como Educação), sendo acompanhada da seguinte descrição:

A relação entre Estudos Culturais e o campo da educação permanece curiosamente contraditória: ela é subenfatizada no circuito dos estudos culturais em termos das relações históricas entre os dois campos, todavia, em termos de produção de estudos, expande-se rapidamente nos círculos da educação. Por exemplo, apesar da recorrente afirmação de Raymond Williams de que os estudos culturais se originaram do campo da Educação de Adultos, e apesar do fato de a atuação inicial do Centro de Estudos Culturais Contemporâ$\operatorname{neos}^{26}$ ter incluído trabalho em educação e dois sucessivos Grupos de Educação, a educação de adultos como origem dos estudos culturais foi marginalizada em favor de uma preponderante narrativa que coloca a crise nas Humanidades e nas ciências sociais como momento originário dos EC, e a

${ }^{25}$ Numa tradução livre, os tópicos constantes do Programa são os seguintes: Teoria Cultural; Audiências; Corpo na Sociedade; Cultura do Consumidor e do Consumo; Política Cultural; Estudos Culturais e História; Estudos Culturais, Educação e Pedagogia; Etnia e Raça; Alta e Baixa Arte e Cultura de Massa; Construção da Identidade; Cultura Material; Estudos da Mídia; Metodologia; Nacionalidade e Nacionalismo; Tecnologia da Informação e da Nova Mídia; Cultura Popular; Estudos Culturais da Psicologia; A Cultura das Cidades; Cultura da Juventude; Meio ambiente e Estudos Culturais; Estudos das Profissões; Globalização (as iniciais maiúsculas correspondem ao texto original. O grifo, a nota e a tradução são dos autores deste artigo).

${ }^{26}$ Referência ao Centro de Birmingham. educação não é mais discutida nos círculos dos estudos culturais como um campo contributivo a este debate. Por outro lado, os estudos culturais emergiram e se expandem rapidamente na educação radical na América do Norte como sucessores da teoria e da pedagogia crítica e multicultural, além de estarem sendo institucionalizados em departamentos de estudos culturais e centros de educação. Este painel explora focos como a natureza e o perfil da relação contemporânea entre estudos culturais e educação; a contribuição que estudos culturais e educação podem aportar para seus discursos e práticas; exemplos de projetos concretos que mesclam educação e estudos culturais. ${ }^{27}$

A proposição de um painel com tal descrição coloca em destaque o caráter controvertido dos laços entre Educação e Estudos Culturais, revelando, ao mesmo tempo, estarem eles insuficientemente problematizados e debatidos. No tópico Estudos Culturais, Educação e Pedagogia, além do painel mencionado, cuja justificativa incide especial e centralmente na necessidade de delineamento e debate destas polêmicas e plurifacetadas conexões, um conjunto paralelo de propostas indica o variado matiz das discussões, pesquisas e trabalhos que se inscrevem no âmbito destas aproximações. Abordagens sobre questões de metodologia e política na escolarização dos vários níveis, discussões sobre relações de poder no currículo e na sala de aula, bem como contribuições aos debates sobre infância, cidadania, identidade nacional, pedagogias culturais na pós-modernidade, a cultura do "outro", raça, gênero e etnia no capitalismo neoliberal, efeitos da globalização e do neoliberalismo na educação, o combate à contínua colonização dos saberes e das relações sociais nas escolas emergem das várias propostas formuladas.

${ }^{27}$ A autora desta descrição é Handel Wright, do Programa de Estudos Culturais da Universidade do Tennessee, nos Estados Unidos, que propôs e coordenou, juntamente com Karl Maton, da Universidade de Cambridge, Inglaterra, as atividades relativas ao painel temático assim descrito. Cf. site mencionado da Fourth International Conference Crossroads in Cultural Studies. 
Convém destacar, contudo, que, se continuarmos a percorrer o site desta conferência, perceberemos que de numerosos tópicos - e não só deste intitulado $E s$ tudos Culturais, Educação e Pedagogia - se poderiam recolher contribuições que interessam à educação e que podem ajudar a ampliar a gama de formas de problematização que crivam, matizam e complexificam os debates sobre educação nos dias atuais. Tomando apenas o tópico Teoria cultural, poderemos observar que os painéis abordam as ligações dos Estudos Culturais com conceitos-chave como liberdade, hegemonia, resistência, poder e subordinação. Convocam, também, para uma discussão sobre as consequiências das grandes catástrofes contemporâneas sobre suas vítimas, tais como os êxodos e diásporas causados pelas guerras e outros acontecimentos dramáticos relacionados com atos terroristas, desastres ecológicos e a violência nos centros urbanos, nas periferias e no campo, em muitos países. As conexões entre cultura e poder são enfatizadas nos trabalhos que procuram desafiar as fronteiras disciplinares mediante estudos que exploram a transdisciplinaridade ou celebram a pós-disciplinaridade. Nessa direção surgem, igualmente, as análises críticas à divisão do trabalho e às fronteiras entre trabalho intelectual acadêmico e não-acadêmico. Incentivam-se debates sobre temáticas emergentes nos movimentos sociais e em circuitos intelectuais fora do eixo Europa - América do Norte. A cultura das cidades é abordada com ênfase nos discursos pós-modernos sobre o espaço urbano. A experiência de viver na cidade é retomada nos cenários e problemáticas urbanas do século XXI, recompondo e explorando representações em que exóticos "outros" são posicionados. Também a natureza é discutida como o "outro" da cultura ocidental, aportando novos e importantes elementos para um criticismo das visões antropocêntricas. Estudos de mídia e literatura são articulados nesse cruzamento com questões ecológicas, delineando novas configurações e espaços para o encaminhamento destas preocupações.

Esse breve e superficial levantamento das questões abordadas por apenas mais um dos tópicos - Teo- ria cultural -, dentre os $21^{28}$ indicados para articular as discussões da "comunidade" internacional dos EC, constitui uma boa amostra de sua vitalidade. Não se verifica apenas uma surpreendente diversificação da gama de temáticas culturais, como também uma ampla transformação no que diz respeito a questionamentos e problematizações.

Se desejarmos pensar em Estudos Culturais em Educação na América Latina, isso implica, mais uma vez, refletirmos sobre os entendimentos compartilhados acerca desse campo ou desse movimento que cruza fronteiras, inaugura formas diferentes de pensar sobre quase tudo que acreditávamos resolvido, e não se quer estável, definitivo, certo, demarcado, aprisionado em territórios geográficos, disciplinares, teóricos ou temáticos. Uma possibilidade é conceber os Estudos Culturais em Educação como um partilhamento de entendimentos, de conceitos-chave e "formas de olhar" que eles trouxeram, principalmente, para as áreas das humanidades, da comunicação, da literatura. Entretanto, isso soa um tanto parcial e inexato, uma vez que não se trata apenas de "partilhar", "apropriar-se" ou "utilizar"; as "lentes" dos EC parece que vêm possibilitando entender de forma diferente, mais ampla, mais complexa e plurifacetada a própria educação, os sujeitos que ela envolve, as fronteiras. De certa maneira, pode-se dizer que os Estudos Culturais em Educação constituem uma ressignificação e/ou uma forma de abordagem do campo pedagógico em que questões como cultura, identidade, discurso e representação passam a ocupar, de forma articulada, o primeiro plano da cena pedagógica.

Se pensarmos o quanto a educação, a partir das contribuições da teoria crítica, vem se configurando como uma área de militância, de atuação política, vêse quase como inevitável esta aproximação com os EC, já que estes também, em sua constituição e desenvolvimentos, têm uma face histórica de imbricações com a atividade política e crítica. Em contrapartida, a educação e a pedagogia têm se valido de vários outros cam-

\footnotetext{
${ }^{28}$ Ver nota 23.
} 
pos disciplinares (Psicologia, Sociologia, Política, Medicina, Administração, para citar os mais conhecidos), às vezes de maneira mais restrita - vejam-se, por exemplo, entendimentos da pedagogia como mera adaptação de "ações" a presumíveis "formas de aquisição dos conhecimentos", predominantes nas chamadas pedagogias psi - outras, de maneira mais eclética, o que tem sido mais freqüente. Assim, na medida em que os EC incursionam por vários campos disciplinares, recolhendo, adaptando e aproveitando metodologias, achados etc., há uma certa "homologia" neste caráter híbrido tanto da educação quanto dos EC.

Se voltarmos nosso enfoque para as conexões entre os Estudos Culturais da América Latina e o amplo campo da educação, poderíamos experimentar uma decepção inicial diante da escassez de trabalhos que tematizem tal relação. Não podemos, entretanto, cair na cilada de que nada tenha sido dito ou feito nessa direção. Por um lado, temos esporádicas - mas não banais - reflexões sobre o papel e as características da escola dentro desse novo mundo híbrido, vista como um espaço em mudança nas novas configurações culturais. Por outro lado, é forçoso reconhecer a existência de estudos na área educacional que - principalmente através da influência dos olhares foucaultianos, da visão cultural e outros da pós-modernidade - aproximamse grandemente do que se tem pensado no Brasil como Estudos Culturais em Educação. O abandono das metanarrativas da modernidade, a concepção da educação como campo de disciplinamento e de subjetivação, a consideração das dimensões de etnia, gênero, inclusive utilizando (outros) autores, como Kellner e Hall, marcam tais obras como temática e teoricamente aparentadas aos Estudos Culturais. ${ }^{29}$

${ }^{29}$ Mariano Narodowski, Inês Dussel, Violeta Guyot, Silvina Gvirtz, Adriana Puigróss são alguns dos autores latino-americanos que têm problematizado a educação sob um ponto de vista pósmoderno inspirado em leituras foucaultianas, inclusive se abeberando em alguns autores dessa vertente tanto no além-mar, como os espanhóis Jorge Larrosa, Julia Varela, Fernando Álvarez-Uría, e no Brasil, e Alfredo Veiga-Neto e Tomaz Tadeu da Silva.
Voltando à primeira hipótese - à abordagem da educação dentro das análises culturais, vemos que Canclini, por exemplo, em Culturas híbridas, não silencia sua reflexão frente aos muros da escola, mas a insere em seu poderoso pensamento, a partir, no caso específico, de um postulado "A escola é um palco fundamental para a teatralização do patrimônio" (Canclini, 1998, p. 164). Dialogando com estudos do campo pedagógico latino-americano, o autor faz breves e poderosas incursões motivadoras sobre os ritos, as práticas e os discursos circulantes na escola da América Latina, os quais tanto auxiliaram a separar os "selvagens" dos "civilizados", intentando construir estes últimos.

Também Sarlo tematiza a questão da escola, mas, diferentemente de outros autores e consoante com seu pensamento analítico, de certa forma lamenta uma escola perdida que não apenas teria sido um "instrumento de dominação", mas também foi, na América Latina (ou apenas na Argentina?), um "lugar simbolicamente rico e socialmente prestigioso" que também "distribuía saberes e habilidades que os pobres só podiam adquirir por meio dela", um "espaço laico, gratuito e teoricamente igualitário onde os setores populares puderam apropriar-se de instrumentos culturais que não deixariam de empregar para seus próprios fins e interesses" (Sarlo, 1997a, p. 117-118). Valendo-se de um retrato melancólico da escola atual, como o "lugar da pobreza simbólica”, a autora argentina questiona os discursos correntes da pedagogia atual, que preconizam um "ensino tecnicamente modernizado que prepare para o trabalho e que, além disso, seja interessante para os alunos" (Sarlo, 2001, p. 104), a partir de aguda e detalhada análise das características das práticas e artefatos culturais contemporâneos.

Como exemplo singular de que idéias advindas dos Estudos Culturais também têm entrado capilarmente na reflexão pedagógica dos países de língua espanhola da América Latina, pode ser citado o recente artigo publicado por Marisa Vásquez Mazzini ${ }^{30}$

\footnotetext{
${ }^{30}$ Doutora em Educação pela Universidade de Buenos Aires,
} docente da mesma Universidade e da Universidad de San Andrés. 
na revista virtual Pensar Iberoamérica - Revista de Cultura, sob o título aparentemente tradicional Resultados para quién? Reflexiones sobre la práctica de la evaluación em la escuela. Lançando mão de abordagens dos estudos culturais (explicitamente citados) a partir de autores como Giroux, McLaren, Grossberg, Steinberg e Kincheloe, a autora busca uma revisão da noção de prática escolar e avaliação.

Entre nós, no Brasil, as contribuições mais importantes dos EC em educação parecem ser aquelas que têm possibilitado: a extensão das noções de educação, pedagogia e currículo para além dos muros da escola; a desnaturalização dos discursos de teorias e disciplinas instaladas no aparato escolar; a visibilidade de dispositivos disciplinares em ação na escola e fora dela; a ampliação e complexificação das discussões sobre identidade e diferença e sobre processos de subjetivação. Sobretudo, tais análises têm chamado a atenção para novos temas, problemas e questões que passam a ser objeto de discussão no currículo e na pedagogia.

Nessa direção, projetos de pesquisa integrados ou individuais, trabalhos de iniciação científica, dissertações de mestrado e teses de doutorado têm sido produzidos nos últimos cinco anos, em especial no âmbito do Programa de Pós-Graduação em Educação da Universidade Federal do Rio Grande do Sul, na linha de pesquisa Estudos Culturais em Educação e em outros grupos que partilham de seu direcionamento teórico. Em uma primeira vertente, poderíamos citar aquelas questões, discursos e artefatos que, tradicionalmente tidos como pedagógicos, são ressignificados: livros didáticos, cartilhas, legislações educacionais, revistas pedagógicas, livros de formação pedagógica para professores, programas e projetos educativos, a própria seriação escolar, a ciclagem e as classes de progressão, a arquitetura escolar. Práticas escolares como a da merenda, da avaliação, ou dos cuidados na educação infantil, entre outras, são problematizadas e constituídas como objetos de estudo sob uma ótica cultural, oportunizando seu esquadrinhamento e análise como produtoras de significados, como imersas em redes de poder e verdade, em discursos circulantes, através dos quais se legitimam determinadas representações de crianças, de menino e de menina, de estudante, de professores e professoras, de trabalho docente, de alfabetismo, de determinados componentes curriculares e de educação.

Outra vertente de estudos tem sido aquela compreendida pela expressão "pedagogia cultural”, a qual, conforme Steinberg e Kincheloe (2001, p. 14), inclui "áreas pedagógicas" entendidas como "aqueles lugares onde o poder é organizado e difundido, incluindose bibliotecas, TV, cinemas, jornais, revistas, brinquedos, propagandas, videogames, livros, esportes etc.". Com base nesse entendimento, têm sido investigados tanto variados veículos da mídia jornalística impressa e televisiva, contemplando não só matérias "informativas" mas também peças publicitárias, quanto produtos de entretenimento, tais como filmes, desenhos animados, seriados de TV; neles se têm buscado esquadrinhar seus "ensinamentos", pertencentes a uma gama também muito variada, valendo-se daqueles referentes à própria educação (escola, "progresso", professora, aluno etc.) e se espraiando para outros campos, como as lições sobre o bem e o mal, sobre o que é ser mulher, sobre o que é ser índio, sobre o que é a nação, sobre o que é natureza, sobre a tecnologia, sobre o nosso corpo, sobre a genética, sobre como nossa relação com os animais nos constitui "humanos" etc. Nessas lições, freqüentemente se estabelece o normal e, concomitantemente, o desviante; o "progressista", sinalizando para o "antiquado"; o certo, sinalizando para o errado, em um panorama que, marcado pelas questões culturais, é naturalizado e mostrado como "moderno", "atual", "biologicamente condicionado", "estando na ordem das coisas".

A questão das identidades - um dos pilares dos EC e que também tem se revelado central nos EC latino-americanos de língua espanhola - emerge com mais força nos trabalhos que discutem a heterogeneidade e hibridação de algumas delas, como as de gênero, de índio, de surdo (não mais visto como um "sujeito deficiente", mas como uma identidade mergulhada 
em cultura própria), regionais (o "gaúcho"), de jovem, de internauta freqüentador dos chats.. ${ }^{31}$ Em tais discussões, o confronto entre o global e o local, entre a modernidade e a pós-modernidade, entre os discursos da tradição e os da contemporaneidade midiática assume um caráter central, num panorama ao qual a educação não se pode furtar, mesmo quando tenta mitigar a complexidade de tais processos.

Registre-se, ainda, que na abordagem de todas essas questões, os estudos culturais em educação - aliás, de acordo com sua vocação transdisciplinar e multifacetada - têm se valido de contribuições metodológicas e teóricas de outros campos, em especial daqueles com os quais mantêm maiores afinidades, como os Estudos Culturais da Ciência, os estudos de Gênero, a abordagem Pós-Colonialista, a análise foucaultiana do discurso, a Semiótica e a Análise Crítica do Discurso, os Estudos de Comunicação, realizando a alquimia conveniente a investigações que se propõem, como diz Giroux (1995) entre outras coisas, a "analisar a forma como a linguagem funciona para incluir ou excluir certos significados, assegurar ou marginalizar formas particulares de se comportar e produzir ou impedir certos prazeres e desejos" (p. 95).

\section{A articulação dos Estudos Culturais com a escola: uma possibilidade}

Finalmente, em nosso percurso pelas movimentações dos EC e por seus cruzamentos com a educação e a pedagogia, encontramos subsídios para afirmar que a educação se dá em diferentes espaços do mundo contemporâneo, sendo a escola apenas um deles. Quer dizer, somos também educados por ima-

${ }^{31}$ Exemplos dessa produção dos Estudos Culturais em educação podem ser encontrados em Estudos culturais em educação e Caminhos investigativos II, organizado por Marisa Vorraber Costa (2000 e 2002a respectivamente); Infância e maquinarias, de Maria Isabel Bujes (2002); Educação em tempos de globalização, organizada por Saraí Schmidt (2001) e Professoras que as histórias nos contam, organizada por Rosa Hessel Silveira (2002). gens, filmes, textos escritos, pela propaganda, pelas charges, pelos jornais e pela televisão, seja onde for que estes artefatos se exponham. Particulares visões de mundo, de gênero, de sexualidade, de cidadania entram em nossas vidas diariamente. É a isto que nos referimos quando usamos as expressões currículo cultural e pedagogia da mídia. Currículo cultural diz respeito às representações de mundo, de sociedade, do eu, que a mídia e outras maquinarias produzem e colocam em circulação, o conjunto de saberes, valores, formas de ver e de conhecer que está sendo ensinado por elas. Pedagogia da mídia refere-se à prática cultural que vem sendo problematizada para ressaltar essa dimensão formativa dos artefatos de comunicação e informação na vida contemporânea, com efeitos na política cultural que ultrapassam e/ou produzem as barreiras de classe, gênero sexual, modo de vida, etnia e tantas outras.

Esta é uma preocupação central nos Estudos Culturais Contemporâneos, que Giroux (1995) sintetiza como "o estudo da produção, da recepção e do uso situado de variados textos, e da forma como eles estruturam as relações sociais, os valores e as noções de comunidade, o futuro e as diversas definições do eu" (p. 98). O próprio sentido de texto é alargado, referindo-se a sons, imagens e dispositivos microeletrônicos como os computadores e a Internet. Trata-se de textos culturais que no mundo contemporâneo atravessam as fronteiras entre Estados Nacionais, cidades e comunidades. É porque hoje nossos alunos e alunas passam mais tempo em frente à televisão do que na escola (mas não apenas por isso), que o sentido de realidade foi incrivelmente expandido. Simplesmente não podemos mais dizer que partimos da realidade se não considerarmos o poder constituidor e subjetivador da mídia no mundo atual.

Num breve recorte ilustrativo das aproximações dos EC com a escola, queremos ressaltar, ainda, que os objetos e temáticas que vimos mencionando estão relacionados com o que presenciamos em nossas salas de aula hoje. Se até pouco tempo atrás ensinar a partir da realidade significava considerar as particularidades sociais, econômicas e culturais de um gru- 
po de alunos, vamos argumentar que o conceito de realidade foi sensivelmente ampliado para além de qualquer idéia de comunidade, de espaço, tempo e lugar e, especialmente, de uma identidade cultural estável. Tal compreensão, parece-nos, está diretamente implicada com o que vemos e deixamos de ver em nossas salas de aula e, logo, com as direções, com as escolhas que fazemos em termos do que ensinar e como ensinar. Se nos EC, a cultura é uma arena, um campo de luta em que o significado é fixado e negociado, as escolas, sua maquinaria, seus currículos e práticas são parte desse complexo.

Uma aproximação com o currículo pode ser feita baseando-se na noção de campo de luta, crescentemente utilizada nas análises curriculares críticas e póscríticas $^{32}$ que lançam mão da teoria cultural contemporânea. Quer dizer, "podemos ver o conhecimento e o currículo como campos culturais, como campos sujeitos à disputa e a interpretação, nos quais os diferentes grupos tentam estabelecer sua hegemonia" (Silva, 1999b, p. 135). Sendo construído culturalmente, o currículo reflete o resultado de um embate de forças e seus saberes e práticas investem na produção de tipos particulares de sujeitos e identidades sociais.

Esta noção, tomando contribuições do pensamento pós-estruturalista, especialmente aquela proveniente dos trabalhos de Michel Foucault, procura destacar uma certa dimensão do conceito de poder que alarga

32 As publicações contendo análises nestas vertentes são numerosas, hoje, no Brasil. Citamos, dentre elas, Territórios Contestados (organizado por Tomaz T. da Silva e Antonio Flávio Moreira, 1995, Vozes), Alienígenas na sala de aula (organizado por Tomaz T. da Silva, 1995, Vozes), O currículo nos limiares do contemporâneo (organizado por Marisa Vorraber Costa, 1998, DP\&A), Documentos de identidade (organizado por Tomaz T. da Silva, 1999, Autêntica), Currículo : políticas e práticas (organizado por Antonio Flávio Moreira, 1999, Papirus), Currículo, práticas pedagógicas e identidades (organizado por Antonio Flávio Moreira e Elizabeth Macedo, 2002, Porto) e Currículo: debates contemporâneos (organizado por Alice Casemiro Lopes e Elizabeth Macedo, 2002, Cortez). os sentidos circulantes na tradição crítica. Em outras palavras, não se trata de pura e simplesmente destacar que os grupos que estão em posição hierarquicamente superior em uma relação de poder definem o que deve ser ensinado, o que de fato ocorre, mas se trata de considerar a produtividade do poder, para além do binarismo dominadores e dominados. Em outras palavras, o que precisamos continuar a investigar, discutir, destacar, mostrar é a positividade do poder, sua capacidade de produzir subjetividades e identidades. É nesta direção que os Estudos Culturais têm enfatizado a produtividade dos poderes e saberes no ordenamento da vida social.

No que se refere ao papel do professor e da professora, novas formas de conceber a escola, os conhecimentos e o currículo, desafiam-nos a ultrapassar a noção de transmissores de informações. Sobretudo, seríamos produtores culturais e nossas práticas pedagógicas deveriam privilegiar a organização de experiências através das quais os estudantes pudessem vislumbrar o caráter socialmente construído "de seus conhecimentos e experiências, num mundo extremamente cambiante de representações e valores" (Giroux, 1995, p. 101).

Não se pode perder de vista uma dimensão do currículo como "lugar de circulação de narrativas, [...] lugar privilegiado dos processos de subjetivação, da socialização dirigida, controlada" (Costa, 1998, p. 51). Ainda que o ideário emancipatório seja o norte de nossas práticas docentes, ainda que objetivemos formar cidadãos críticos e autônomos, e que tais concepções sustentem a seleção dos conhecimentos e experiências que compõem o currículo, o que fazemos é estruturar o campo de ação do outro, é governar sujeitos (Foucault, 1995). Através das palavras que escolhemos (nos escolheram) para olhar para a educação escolar e o currículo estamos compondo uma certa representação de realidade e dirigindo condutas, produzindo determinados tipos de subjetividades e identidades, sintonizados com a realidade que as palavras compõem.

MARISA VORRABER COSTA é doutora em ciências humanas e professora titular em ensino e currículo. Atua presente- 
mente nos programas de pós-graduação em Educação da ULBRA e da UFRGS, no campo dos Estudos Culturais em Educação. Coordena o Núcleo de Estudos sobre Currículo, Cultura e Sociedade (NECCSO) e é pesquisadora do CNPq. O último livro que organizou é Caminhos investigativos II - outros modos de pensar e fazer pesquisa em educação (DP\&A, 2002). E-mail : vorraber@portoweb.com.br

ROSA HESSEL SILVEIRA é doutora em educação e professora titular aposentada da Faculdade de Educação da UFRGS. Atua presentemente nos programas de pós-graduação em Educação da ULBRA e da UFRGS, no campo dos Estudos Culturais em Educação. É pesquisadora do CNPq e integrante do NECCSO. Recentemente publicou o livro Professoras que as histórias nos contam (DP\&A, 2002).E-mail: rosamhs@terra.com.br

LUIS HENRIQUE SOMMER é doutor em educação pela UFRGS; pesquisador do NECCSO; professor dos cursos de Pedagogia e Normal Superior do Centro Universitário Feevale (RS); professor do curso de pedagogia e Programa de Pós-Graduação em Educação da ULBRA. Entre seus trabalhos mais recentes está sua tese de doutorado intitulada Computadores na escola : a produção de cérebros-de-obra.E-mail: henriquesommer@uol.com.br

\section{Referências bibliográficas}

ALASUUTARI, Pertti, (1999). Cultural studies as a construct. European journal of cultural studies, v. 2, n 1, p. 91-108, jan.

BARKER, Martin, BEEZER, Anne, (eds.) (1994). Introducción a los estudios culturales. Barcelona: Bosch Casa Editorial. Tradução de Héctor Borrat.

BUJES, Maria Isabel E., (2002). Infância e maquinarias. Rio de Janeiro: DP\&A.

CANCLINI, Néstor García, (1995). Consumidores e cidadãos: conflitos multiculturais da globalização. Rio de Janeiro: Editora da UFRJ.

, (1997a). El malestar en los estudios culturales. Fractal, México, ano 2, v. 2, nº 6, p. 45, jul/sept. Disponível em: <http:/ /www.fractal.com.mx/F6cancli.html>. Acesso em: 1 mar. 2003. , (1997b). Contrasting perspectives: cultural studies in Latin América and the United States: a conversation with
Néstor García Canclini. Cultural Studies, v. 1, nº 11, p. 78-88. Interview and translation by Patrick D. Murphy.

, (1998). Culturas híbridas: estratégias para entrar e sair da modernidade. São Paulo: EDUSP.

CASTRO-GÓMEZ, Santiago, (2000). Ciencias sociales, violência epistémica y el problema de la "invención del otro". In: LANDER, E. (org. ). La colonialidad del saber : eurocentrismo y ciencias sociales: pespectivas latinoamericanas. Buenos Aires: Consejo Latinoamericano de Ciencias Sociales, p. 145-161.

COSTA, Marisa Vorraber, (1998). Currículo e política cultural. In : , (org.). O currículo nos limiares do contemporâneo. Rio de Janeiro: DP\&A. , (org.) (2000). Estudos culturais em educação. Mídia, arquitetura, brinquedo, biologia, literatura, cinema... Porto Alegre: Editora da UFRGS.

, (org.) (2002a). Caminhos investigativos II : outros modos de pensar e fazer pesquisa em educação. Rio de Janeiro: DP\&A.

(2002b). Poder, discurso e política cultural: contribuições dos estudos culturais ao campo do currículo. In: LOPES, Alice Casemiro, MACEDO, Elizabeth, (orgs.). Currículo: debates contemporâneos. São Paulo: Cortez.

, (2002c). O papel dos estudos culturais na atualidade. Nova América, $\mathrm{n}^{\circ}$ 96, dez.

ESCOSTEGUY, Ana Carolina, (2001). Cartografia dos estudos culturais - uma versão latino-americana. Belo Horizonte: Autêntica.

FOLLARI, Roberto A., (2000). Estudios sobre postmodernidad y estudios culturales: ¿sinónimos? Revista Latina de Comunicación Social, La Laguna, ano 3, n 35, nov. Disponível em: <http:// www.ull.es/publicaciones/latina/argentina2000/15follari.htm>. Acesso em: 16 mar. 2003.

FOUCAULT, Michel, (1995). O sujeito e o poder. In : DREYFUS, Hubert L., RABINOW, Paul. Michel Foucault - uma trajetória filosófica: para além do estruturalismo e da hermenêutica. Rio de Janeiro: Forense Universitária. , (2000). A arqueologia do saber. Rio de Janeiro: Forense.

FROW, John, MORRIS, Meaghan, (1997). Australian cultural studies. In: STOREY, John, (ed.). What is cultural studies? A reader. $2^{\mathrm{a}}$ ed. London: Arnold. 
GIROUX, Henry A., (1995). Praticando estudos culturais nas faculdades de educação. In: SILVA, Tomaz T. da, (org.). Alienígenas na sala de aula: uma introdução aos estudos culturais em educação. Rio de Janeiro: Vozes.

HALL, Stuart, (1996). Cultural studies and its theoretical legacies. In : MORLEY, David, KUAN-HSING, C., (eds). Stuart Hallcritical dialogues in cultural studies. London; New York: Routledge.

, (1997a). Race, culture and communications: looking backward and forward cultural studies. In: STOREY, John, (ed.). What is ultural studies? A reader. $2^{\mathrm{a}}$ ed. London: Arnold. , (1997b). A centralidade da cultura: notas sobre as revoluções culturais do nosso tempo. Educação \& Realidade, v. $22, \mathrm{n}^{\mathrm{o}} 2$, jul./dez.

(1997c). Cultural Studies: two paradigms. In: STOREY, John, (ed.). What is cultural studies? A reader. $2^{\mathrm{a}}$ ed. London: Arnold.

, (2000). O legado teórico dos cultural studies. Revista de Comunicação e Linguagens, Universidade Nova de Lisboa, $n^{\circ} 28$, out.

JOHNSON, Richard, (1986/7). What is cultural studies anyway? Social Text, 16.

, (1999). O que é, afinal, estudos culturais? In: SILVA,

Tomaz T. da, (org.). O que é, afinal, estudos culturais. Belo Horizonte: Autêntica.

LARROSA, Jorge, (2002). Notas sobre a experiência e o saber de experiência. Revista Brasileira de Educação. Campinas, $\mathrm{n}^{\circ}$ 19, p. 20-28, jan./fev./mar./abr.

LOS estudios culturales en latinoamerica. Campus Virtual de CLACSO, Cursos de formación a distancia para el año 2003, Aula 537. Disponível em: <http://campus.clacso.edu.ar/html/ cursos/537.html>. Acesso em: 22 mar. 2003

MARTÍN-BARBERO, Jesús, (1997a). Dos meios às mediações: comunicação, cultura e hegemonia. Rio de Janeiro: Editora UFRJ. , (1997b). "Nosotros habíamos hecho estudios culturales mucho antes que esta etiqueta apareciera": una entrevista con Jesús Martín-Barbero. Dissens, Colômbia, n 3, p. 47-53. Entrevista concedida a Ellen Spielmann. Disponível em: <http:// www.javeriana.edu.co/pensar/Rev33.html >. Acesso em 31 mar. 2003.
MATO, Daniel, (coord.) (2001). Estudios y otras prácticas latinoamericanas en cultura y poder: crítica de la idea de "Estudios culturales Latinoamericanos" y Propuestas para la visibilización de un campo más amplio, transdisciplinario, crítico y contextualmente referido. Disponível em: <http:// www.geocities.com/global_cult_polit/QuitoJunio2001. doc>. Acesso em: 8 mar. 2003. Trabalho apresentado no Seminário Geopolíticas de Conocimiento en América Latina e Primer Encuentro Internacional sobre "Estudios culturales latinoamericanos: retos desde y sobre la región andina”, Quito.

MOREIRAS, Alberto, (2001). A exaustão da diferença: a política dos estudos culturais latino-americanos. Belo Horizonte: Ed. UFMG.

NELSON, Cary, TREICHLER, Paula, GROSSBERG, Lawrence, (ed.) (1992). Cultural Studies. New York/London, Routledge.

RÍOS, Alicia, (2002). Los estudios culturales y el estúdio de la cultura em América Latina. In: MATO, D., (coord.). Estudios y otras prácticas intelectuales latinoamericanas en cultura $y$ poder. Caracas: Consejo Latinoamericano de Ciencias Sociales (CLACSO) y CEAP, FACES, Universidad Central de Venezuela. p. 247-254. Disponível em: <http://www.globalcult.org.ve/ Alicia\%20R\%EDos\%20.pdf>. Acesso em: 31 mar. 2003.

SARDAR, Ziauddin, VAN LOON, Boris, (1998). Introducing cultural studies. New York: Totem Books.

SARLO, Beatriz, (1997a). Cenas da vida pós-moderna - intelectuais, arte e vídeo-cultura na Argentina. Rio de Janeiro: Editora UFRJ.

(1997b). Paisagens imaginárias - intelectuais, arte e meios de comunicação. São Paulo: EDUSP.

, (2001). Tiempo presente. Notas sobre el cambio de una cultura. Buenos Aires: Siglo Veintiuno Editores.

SCHMIDT, Saraí, (org.) (2001). A educação em tempos de globalização. Rio de Janeiro: DP\&A, 2001.

SCHWARZ, Bill, (2000). Onde estão os cultural studies? Revista de Comunicação e Linguagens, Universidade Nova de Lisboa, $\mathrm{n}^{\mathrm{o}} 28$, out.

SILVA, Juremir M., (2003). Do popular ao pop. Correio do Povo, Porto Alegre, 12 fev., p. 4.

SILVA, Tomaz T. da, (1999a). Documentos de identidade: uma introdução às teorias do currículo. Belo Horizonte: Autêntica. 
(org.) (1999b). O que é, afinal, estudos culturais?

Belo Horizonte: Autêntica.

SILVEIRA, Rosa Maria Hessel, (org.) (2002). Professoras que as histórias nos contam. Rio de Janeiro: DP\&A.

STEINBERG, Shirley, KINCHELOE, Joe, (orgs.) (2001). Cultura infantil: a construção corporativa da infância. Rio de Janeiro: Civilização Brasileira.

STOREY, John, (Ed.), (1997). What is cultural studies? A reader. $2^{\mathrm{a}}$ ed. London: Arnold.

VATTIMO, Gianni, (1991). A sociedade transparente. Rio de Janeiro: Edições 70. Tradução de Carlos Aboim de Brito.
VEIGA-NETO, Alfredo, (2000). Michel Foucault e os estudos culturais. In: COSTA, Marisa V. (org.). Estudos culturais em educação. Porto Alegre: Editora da UFRGS.

VERDESIO, Gustavo, (2003). Andanzas y vaivenes teóricos y epistemológicos en um mundo comunicado. Disponível em: <http://www.henciclopedia.org.uy/autores/Verdesio/ MundoComunicado.htm>. Acesso em: 27 mar. 2003.

WILLIAMS, Raymond, (1992). Cultura. Rio de Janeiro: Paz e Terra. Recebido em março de 2003 Aprovado em março de 2003 